\title{
Mycosis Fungoides and Sezary Syndrome T3 TNM Finding v7
}

National Cancer Institute

\section{Source}

National Cancer Institute. Mycosis Fungoides and Sezary Syndrome T3 TNM Finding v7. NCl Thesaurus. Code C88234.

One or more tumors (equal or greater than $1 \mathrm{~cm}$ diameter). Note: for skin, tumor indicates at least $1 \mathrm{~cm}$ diameter solid or nodular lesion with evidence of depth and/or vertical growth. Note total number of lesions, total volume of lesions, largest size lesion, and region of body involved. Also note if histologic evidence of large-cell transformation has occurred. Phenotyping for CD30 is encouraged. (from AJCC 7th Ed.) 